\title{
MICROBIOLOGICAL EVALUATION OF MOZZARELLA CHEESE
}

\author{
DINA. N. ALI and WALAA M.A. ELSHERIF
}

Animal Health Research Institute, Assiut Regional Laboratory

Email: dinanour2010@yahoo.com

\section{ABSTRACT}

Received at: $28 / 12 / 2014$

Accepted: 15/1/2015
Mozzarella cheese is a good source of nutrients namely protein, fat, minerals and vitamins. The study was performed to evaluate the microbiological quality of Mozzarella cheese and it's correlation with Egyptian and International standards. A total of 50 mozzarella cheese samples were collected from supermarkets in Assiut City, Egypt. All samples were investigated to determine the total aerobic plate, yeasts, molds and coliforms counts also, for detection of Staph. aureus, E. coli and Salmonella spp. In the examined samples the incidence of yeasts, molds and coliforms were 94, 32 and $96 \%$, respectively while, Staph. aureus, E. coli and Salmonella were detected in 24,20 and $12 \%$ of the examined samples. The microbiological results in this study were compared with the limits of Egyptian Organization Standards and International Standards.

Key words: Mozzarella cheese, Microorganism, Egyptian Organization Standards

\section{INTRODUCTION}

Mozzarella cheese is asemi hard, white, unripened has very lively surface sheen and has unique property of stretch-ability. It owes its characteristics mainly to the action of lactic acid on dicalcium-paracaseinate that may be consumed shortly after manufacture. Its melting and stretching characteristics are highly appreciated in the manufacture of pizza, where it serves as a key ingredient (Jana and Mandal, 2011).

Mozzarella has been the ubiquitous increase in the popularity of pizza, in which mozzarella is the main cheese used. The functional attributes of importance for pizza include the desired degrees of flow and stringiness on baking. The cheeses best endowed with these characteristics, especially stretch-ability, are members of the pasta-filata group (Fox et al., 2000).

Milk used for cheese manufacture is required to be pasteurized at $72^{\circ} \mathrm{C}$ for $15 \mathrm{~s}$ or its equivalent, according to US Food and Drug Administration (FDA) regulations (FDA, 2011), which destroys most common pathogenic or spoilage bacteria. However, heat-resistant pathogenic and spoilage bacteria may be present in raw milk or equipment surfaces, and even non-heat resistant bacteria may gain access during cheese manufacture and storage (Kikuchi et al., 1996). The presence of these bacteria is detrimental to cheese shelf life and quality (El-Gazzar and Marth, 1992; Schlesser et al., 2006). Although Mozzarella cheese might be contaminated with pathogens, such as Salmonella serovars (De Felip and
Toti 1984), Staphylococcus aureus (Bowen and Henning, 1994) and Listeria monocytogenes (Buazzi et al., 1992). Similarly, the Stx2 shiga toxin produced by enterohemorrhagic Escherichia coli O157:H7 is resistant to milk pasteurization and other equivalent heat treatments and is destroyed only by $100^{\circ} \mathrm{C}$ for 5 min (Rasooly and Do, 2010).

Microbial contamination, causing approximately onefourth of the world's food supply loss, has become an enormous economic and ethical problem worldwide (Huis in't Veld, 1998). Dairy products are an excellent growth medium for a wide range of microorganisms and, thus, display a reduced shelf life (Ruegg, 2003). The microbiological quality of dairy products is influenced by the initial flora of raw milk, the processing conditions, and post-heat treatments. Spoilage bacteria and various bacteria of public health concern can be found in these products and their concentrations should be kept as low as possible (Varga, 2007).

Therefore, the aim of this work was to evaluate the quality of mozzarella cheese and compare the results with Egyptian Organization Standards and International Standards.

\section{MATERIALS and METHODS}

A total of 50 mozzarella cheese samples were taken for analyses aseptically after few hours of collection from supermarkets in Assiut City, Egypt. The samples were collected in clean plastic bags as 
marketed to the consumers and transported, as soon as, possible to be examined for:-

1- Total viable count according to A.P.H.A. (1992).

2- Yeasts and molds counts according to Harrigan and MeCance (1976).

3- Total coliform counts (MPN) according to FAO (1992).

4- Isolation of Staph. aureus according to A.O.A.C. (2000).

5- Isolation of E.coli: Samples were prepared to isolate the E. coli according to FAO (1992).

6- Isolation of Salmonella according to Wallace et al. (2009).

\section{A- Serodiagnosis of E.coli:}

This part has been done in the Food Hygiene Lab in the Faculty of Veterinary Medicine of Moshtohor, Banha Univ., Egypt.

The isolates were serologically identified according to Kok et al. (1996) by using rapid diagnostic E. coli antisera sets for diagnosis of the Enteropathogenic types. The technique applied as recommended by the manufacture (DENKA SEIKEN Co., Japan).

\section{B. Serological identification of Salmonellae:}

Serological identification of Salmonellae was carried out according to Kauffman - White scheme (Kauffman, 1974) for the determination of Somatic (O) and flagellar (H) antigens using Salmonella antiserum (DENKA SEIKEN Co., Japan).

\section{Identification of total Staphylococci species:}

Morphological examination (Cruickshank et al., 1975).

\section{Biochemical identification:}

Catalase activity test (MacFaddin, 1976).

Detection of haemolysis (Collins and Lyne, 1984). Mannitol fermentation test (Bailey and Scott, 1978). Coagulase test (Baron et al., 1994).

Thermostable nuclease test "D-Nase activity" (Lachia et al., 1971).

D-Nase agar plates were inoculated with loopfuls of suspected colonies by spotting them on small areas of the plates which incubated at $37^{\circ} \mathrm{C}$ for 18 hours. Moreover, the incubated plates were flooded with normal hydrochloric acid which precipitated DNA resulting in cloudiness of the plates. Accordingly, Appearance of a clear zone around the colony indicated the production of D Nase and recorded as positive result.

\section{RESULTS}

Table 1: Statistical analytical results of microbiological examination of Mozzarella cheese samples.

\begin{tabular}{|c|c|c|c|c|c|}
\hline \multirow{3}{*}{ Microbial Examination } & \multicolumn{5}{|c|}{ Results of mozzarella counts (cfu/g) } \\
\hline & \multicolumn{2}{|c|}{ Positive Samples } & \multirow{2}{*}{ Min. } & \multirow{2}{*}{ Max. } & \multirow{2}{*}{ Average } \\
\hline & No./50 & $\%$ & & & \\
\hline SPC & 50 & 100 & $4 \times 10^{3}$ & $1.8 \times 10^{7}$ & $3.84 \times 10^{6}$ \\
\hline Coliform count & 48 & 96 & $<3$ & $1 \times 10^{2}$ & $8.5 \times 10$ \\
\hline Yeasts & 47 & 94 & 0 & $9 \times 10^{6}$ & $3.2 \times 10^{6}$ \\
\hline Molds & 16 & 32 & 0 & $6 \times 10^{5}$ & $6.8 \times 10^{4}$ \\
\hline
\end{tabular}

Table 2: Incidence of Staph.aureus, E.coli and Salmonellae recovered from Mozzarella cheese samples.

\begin{tabular}{ccc}
\hline \multirow{2}{*}{ Types of M.Os } & \multicolumn{2}{c}{ Positive samples } \\
\cline { 2 - 3 } & No./50 & \% \\
\hline Staph. aureus & 12 & 24 \\
\hline E.coli & 10 & 20 \\
\hline Salmonellae & 6 & 12 \\
\hline
\end{tabular}


Table 3: Serological identification of E.coli strains isolated from Mozzarella.

\begin{tabular}{cccc}
\hline Serodiagnosis & \multicolumn{2}{c}{ Positive samples } & $\begin{array}{c}\text { Strain } \\
\text { characterization }\end{array}$ \\
\cline { 2 - 4 } & No./50 & $\%$ & EHEC* \\
\hline $0157:$ H7 & 1 & 2 & EHEC \\
\hline $055:$ H7 & 4 & 8 & EPEC** \\
\hline O26 & 2 & 4 & EHEC \\
\hline $0128:$ H2 & 2 & 4 & ETEC***
\end{tabular}

- EHEC: - Enterohaemorrhagic E. coli, ** EPEC: - Enteropathogenic E.coli, ***ETEC: - Enterotoxigenic E. coli.

Table 4: Serological identification of Salmonellae strains isolated from Mozzarella.

\begin{tabular}{cccccc}
\hline & & \multicolumn{2}{c}{ Antigenic structure } & \multicolumn{2}{c}{ Positive strains } \\
\cline { 3 - 6 } Identified strains & Group & $\mathbf{O}$ & $\mathbf{H}$ & No./50 & \% \\
\hline Salmonella Typhimurium & $\mathbf{B}$ & $1,4,5,12$ & $\mathrm{i}: 1,2$ & 3 & 6 \\
\hline Salmonella Virchow & C2 & $1,9,12$ & $\mathrm{~g}, \mathrm{~m}:-$ & 1 & 2 \\
\hline Salmonella Haifa & B & $1,4,5,12$ & $\mathrm{Z} 10: 1,2$ & 1 & 2 \\
\hline Salmonella Enteritidis & D1 & $1,9,12$ & $\mathrm{~g}, \mathrm{~m}: 1,7$ & 1 & 2 \\
\hline
\end{tabular}

Table 5: Identification of S.aureus strains isolated from Mozzarella.

\begin{tabular}{clcc}
\hline \multirow{2}{*}{ Identified bacterium } & Further Identification & \multicolumn{2}{c}{ Positive strains } \\
\cline { 3 - 4 } & Coagulase +ve / DNase -ve & $\mathbf{5}$ & $\mathbf{1 0}$ \\
\hline Staph. aureus & Coagulase +ve / DNase +ve & $\mathbf{4}$ & $\mathbf{8}$ \\
\hline Staph. aureus & Coagulase -ve / DNase -ve & $\mathbf{3}$ & $\mathbf{6}$ \\
\hline
\end{tabular}

Table 6: Summarized results of microbiological examination of Mozzarella cheese samples compared with the International Standards (IDF, 1984).

\begin{tabular}{|c|c|c|c|c|c|}
\hline \multirow{3}{*}{ Organisms } & \multirow{3}{*}{ Requirements } & \multicolumn{4}{|c|}{ Mozzarella cheese samples examined } \\
\hline & & \multicolumn{2}{|c|}{ Acceptable } & \multicolumn{2}{|c|}{ Unacceptable } \\
\hline & & No./50 & $\%$ & No./50 & $\%$ \\
\hline Total plate count/g & Max. 50.000 & 1 & 2 & 49 & 98 \\
\hline Coliform count & Absent in $0.1 \mathrm{~g}$ & 2 & 4 & 48 & 96 \\
\hline E.coli & Absent in $1 \mathrm{~g}$ & 40 & 80 & 10 & 20 \\
\hline Salmonella & Absent in $25 \mathrm{~g}$ & 44 & 88 & 6 & 12 \\
\hline Staph.aureus & Absent in $1 \mathrm{~g}$ & 38 & 76 & 12 & 24 \\
\hline Yeast count & Absent in $1 \mathrm{~g}$ & 3 & 6 & 47 & 94 \\
\hline Mold count & Absent in $1 \mathrm{~g}$ & 34 & 68 & 16 & 32 \\
\hline
\end{tabular}


Table 7: Summarized results of microbiological examination of Mozzarella cheese samples compared with the Egyptian Standards (E.O.S.Q.C., 2005).

\begin{tabular}{cccccc}
\hline \multirow{2}{*}{ Organisms } & Requirements & \multicolumn{3}{c}{ Mozzarella cheese samples examined } \\
\cline { 3 - 6 } & & \multicolumn{2}{c}{ Acceptable } & \multicolumn{2}{c}{ Unacceptable } \\
\cline { 3 - 6 } & & No./50 & $\%$ & No./50 & $\%$ \\
\hline Coliform count & 10 cells/g & 5 & 10 & 45 & 90 \\
\hline E.coli & Absent & 40 & 80 & 10 & 20 \\
\hline Salmonella & Absent & 44 & 88 & 6 & 12 \\
\hline Staph.aureus & Absent & 38 & 76 & 12 & 24 \\
\hline Yeast count & 400 cells/g & 3 & 6 & 47 & 94 \\
\hline Mold count & 10 cells/g & 34 & 68 & 16 & 32 \\
\hline
\end{tabular}

\section{DISCUSSION}

The total bacterial count gives a quantitative idea of the presence of mesophilic aerobic microorganisms of animal origin. It serves as an important criterion to evaluate the microbial quality of various foods and also the degree of freshness of food (Nanu et al., 2007). Data presented in Table 1 illustrated that total bacterial count in examined mozzarella cheese samples ranged from $4 \times 10^{3}$ to $1.8 \times 10^{7}$ with an average count of $3.84 \times 10^{6}$ bacteria /g, Francesca et al. (2014) reported nearly similar results which indicated that the TBC in mozzarella cheese was in the range of $10^{3}$ to $10^{5}$ organisms $/ \mathrm{g}$, similar results were also obtained by Asperger (1991) who reported that the total bacterial count in mozzarella cheese stored at $4{ }^{\circ} \mathrm{C}$ increased and was $>10^{7} \mathrm{cfu} / \mathrm{g}$ after 1 week of storage. Also, Tanweer (2011) detected the initial TBC in mozzarella cheese samples $1 \times 10^{6} \mathrm{cfu} / \mathrm{g}$ and increased to $8 \times 10^{6} \mathrm{cfu} / \mathrm{g}$ after 5 weeks of storage and reported that presence of atmospheric air and $\mathrm{O}_{2}$ affect the overall quality of mozzarella cheese during storage, Also the highly nutritious nature of dairy products makes them especially good media for the growth of microorganisms. Milk contains abundant water and nutrients and has a nearly neutral $\mathrm{pH}$. The major sugar, lactose, is not utilized by many types of bacteria, and the proteins and lipids must be broken down by enzymes to allow sustained microbial growth (Loralyn and Robert, 2009).

Also, in Table 1 coliforms were present in $96 \%$ of samples with an average count of $8.5 \times 10 \mathrm{cfu} / \mathrm{g}$. Higher results were obtained by Tanweer (2011) who found that the initial coliform count was $6 \times 10^{2} \mathrm{cfu} / \mathrm{g}$ in Mozzarella cheese increased to $1000 \mathrm{cfu} / \mathrm{g}$ after 5 weeks of storage. The presence of coliforms or yeasts is indicative of low processing temperature, especially at filling or negligent sanitation. The major microbiological problem with these products is growth of yeasts and molds, especially if free moisture is available at the surface (Marth and Steele, 2001). Moreover some cheese defects may be caused by poor milk quality (late lactation milk, milk from mastitic animals, high in enzymes of animal origin, i.e. lipase and protease), inappropriate rate of acid development by the starter, or poor manufacturing and storage regimens (Fawaz et al., 2011).

In cheese production, slow lactic acid production by starter cultures favors the growth and production of gas by coliform bacteria, with coliforms having short generation times under such conditions. In soft, moldripened cheeses, the $\mathrm{pH}$ increases during ripening, which increases the growth potential of coliform bacteria (Frank, 2001).

Yeasts were presented in $94 \%$ of samples with an average count of $3.2 \times 10^{6}$ cells $/ \mathrm{g}$. while, molds were present in smaller amount only in $32 \%$ of samples with an average count of $6.8 \times 10^{4}$ cells/g (Table 1). Our results were slightly similar to (Tanweer, 2011) who reported that the initial count of yeast and mold counts of mozzarella cheese increased from $5 \times 10^{2}$ to $2 \times 10^{5}$ and $5 \times 10^{5} \mathrm{cfu} / \mathrm{g}$, respectively after 3 weeks of storage at $7 \pm 1{ }^{\circ} \mathrm{C}$.

Molds can grow well on the surfaces of cheeses when oxygen is present, with the low $\mathrm{pH}$ being selective for them. In packaged cheeses, mold growth is limited by oxygen availability, but some molds can grow under low oxygen tension. Molds commonly found growing in vacuum-packaged cheeses include Penicillium spp. and Cladosporium spp. (Hocking and Faedo, 1992). Penicillium is the mold genus most frequently occurring on cheeses.

The results listed in Table 2 indicated that Staph.aureus was existed in $24 \%$, of all examined samples. Staph. aureus is a ubiquitous bacterium, both human and animal commensal (Jay, 2000). Consequently, many foods can be contaminated by this species thus representing hazard for human health.

It is interesting to observe that the heating phase of pasteurization (until milk reached $65^{\circ} \mathrm{C}$ ) produced an 
important lethal effect on Listeria sp., Staphylococcus sp. and especially Salmonella sp. but not on Mycobacterium spp. (Raimundo et al., 2013), While contamination occurs mainly post pasteurization contamination or because of insufficient pasteurization.

Despite of the extensive public health measures over the past century, Salmonella remains the second most commonly identified cause of bacterial foodborne disease in the developed countries and a signficant cause of morbidity and mortality in the developing world (WHO, 2002 and Amin, 2004). 12\% of examined samples were contaminated with Salmonella (Table 2) Although, there are relatively low numbers of positive samples in this study, the pathogen represent a potential risk to consumers on the basis that all salmonellae are potentially pathogenic (Zansky et al., 2002).

Also, Jay (2000) said that the greater efficiency of stretching could be explained by the fact that microorganisms were already injured by curd acidity but this explanation does not elucidate the behavior of Salmonella sp. and Staphylococcus sp. under the same conditions. It is possible that these microorganisms are less sensitive to acid injury than the others. Staph. aureus showing more resistance to stretching than the other microorganisms analyzed.

Escherichia coli are commensal organisms that reside within the host gut, but some pathogenic strains are recognized as a cause of gastroenteritis (Callaway et al., 2003). Table 2 represents the occurrence of E. coli in $20 \%$ of samples. Contamination from human and animal waste is traditionally indicated by the presence of commensal E. coli. Although these organisms are essentially nonpathogenic, their presence warns of the possible concurrent existence of pathogenic microbes (Sherfi et al., 2006).

Table 3, verified serological phenotypic identification of different E.coli isolated from all examined samples. The result represented that O157:H7, O111:H4 and O26 were identified as EHEC. The ETEC strain recognized in serogroups O128:H2 while, EPEC represented in O55:H7.

Foodborne outbreaks of Escherichia coli $0157: \mathrm{H} 7$ infection have been associated with a wide range of food products, including raw and pasteurized milk and milk products, such as cheese (Honish et al., 2005 and Strachan et al., 2005). In the late 1990s, both the U.S. Food and Drug Administration (FDA) and Health Canada proposed bans on the use of raw milk in cheese making.

E. coli $\mathrm{O} 157: \mathrm{H} 7$ can readily contaminate raw milk on the farm because dairy cattle are a known reservoir of Shiga toxin- producing E. coli, including enterohemorrhagic strains such as serotype O157:H7 (Wells et al., 1991). Similarly, the Stx2 shiga toxin produced by enterohemorrhagic E.coli $\mathrm{O} 157: \mathrm{H} 7$ is resistant to milk pasteurization and other equivalent heat treatments and is destroyed only by $100^{\circ} \mathrm{C}$ for 5 min (Rasooly and Do, 2010). Although the presence of Stx 2 in foods is not known to cause illness upon direct consumption, Stx 2 directly fed to mice caused mortality (Rasooly et al., 2010), and may hence be a human health risk.

Salmonellosis is a foodborne infection of major economic importance. According to information gathered from 84 countries responding to a global survey conducted by the World Health Organization (WHO), S. enteritidis and S. typhimurium accounted for $70 \%$ of all human and nonhuman isolates of salmonella reported worldwide between 1995 and 2008 (CDC, 2009). Corresponding to Table 4, it is persisted that the different identified strains of salmonella via sero-typing technique were $6 \%$ S. typhimurium and $2 \%$ S. virchow, S.Haifa and S.enteritidis, respectively.

Some strains of staph.aureus are capable of producing many kinds of enterotoxins (SEs) which are currently being studied deeply and get much attention by the scientific community (Balaban and Rasooly 2000). Enterotoxigenic strains of Staph. aureus have been reported to cause a number of diseases or food poisoning outbreaks because of the ingestion of contaminated dairy products or milk (Asao et al., 2003). Also, Coagulase Negative Staph (CNS) is emerging as important minor mastitis pathogens in Egyptian dairy animals. Such species can cause substantial economic losses resulting in decreased milk production. This reflects the environmental hazard and therefore, udder health must be followed up and control of intra-mammary infections is consequently of the greatest importance for dairy farms (Jakeen et al., 2013). So, further identification was done to Staph. aureus strains, 10, 8 and $6 \%$ of samples were Coagulase +ve / DNase -ve, Coagulase +ve / DNase +ve and Coagulase -ve / DNase - ve, respectively (Table 5).

Comparing the obtained results of examined mozzarella cheese samples with the International Standards (IDF, 1984) (Table 6), 98, 96, 94, 32, 20, 12 and $24 \%$ of samples failed to comply with the limits of the standards which indicated the poorer sanitary practices during cheese production according to TBC, coliforms, yeast, mold count, E.coli, Salmonella and Staph.aureus isolates, respectively.

According to the limits proposed by the E.O.S.Q.C. (2005), only $10,6,68,80,88$ and $76 \%$ of samples were acceptable according to yeast, mold, coliforms count, E.coli. Salmonella and Staph.aureus isolates, respectively (Table 7). This result indicated the 
negligible sanitary control measures during production and handling of the products.

\section{REFERENCES}

A.O.A.C. "Association of Official Analytical Chemists" (2000): Official Methods of Analysis. $17^{\text {th }}$ ed., Washington DC, USA.

A.P.H.A. "American Public Health Association"(1992): Compendium of Methods for the Microbiological Examination of foods. 2nd Ed.,American Public Health Association, Washington, Dc, USA.

Asao, T.; Kumeda, Y.; Kawai, T.; Shibata, T.; Oda, H.; Haruki, K.; Nakazawa, H. and Kozaki, S. (2003): An extensive outbreak of staphylococcal food poisoning due to low-fat milk in Japan: estimation of enterotoxin A in the incriminated milk and powdered skim milk. Epidemiology and Infection 130, 33-40.

Amin, Walaa, F. (2004): Some studies on salmonella species in milk and some milk products in Assiut City. M. V. Sc. Thesis Fac. Vet. Med. Assiut Univ. Egypt.

Asperger, H. (1991): Microbiological hygienic evaluation of Mozzarella cheese. Milchwirtschaft 10(8):138-144.

Bailey, W.R. and Scott, E.G. (1978): Diagnostic Microbiology. A text book for the isolation and identification of pathogenic microorganisms. $5^{\text {th }}$ Ed., Carroll B. Larson and Marjorie Gould Publisher, Saint Louis, C.V. Mosby Co., Missouri, USA.

Balaban, N. and Rasooly, A. (2000): Staphylococcal enterotoxins. International Journal of Food Microbiology 61, 1-10.

Baron, E.J.; Peterson, L.R. and Finegold, S.M. (1994): Bailey and Scott's, Diagnostic Microbiology, $9^{\text {th }}$ ed., st. Louis, Baltimore, USA, Chapter 34:pp.457-473.

Bowen, D.A. and Henning, D.R. (1994): Coliform bacteria and Staph.aureus in retail natural cheese. J. Food Protection.57: 253-255.

Buazzi, M.M.; Johnson, M.E. and Marth, E.H. (1992): Fate of Listeria monocytogenes during the manufacture of Mozzarella cheese. Journal of Food Protection 55, 80-83.

CDC "Centers for Disease Control and Prevention" (2009): Salmonella surveillance: annual summary, 2006. U.S. Department of Health and Human Services, CDC, Atlanta, GA.http://www.cdc.gov /ncidod/dbmd/ phlisdata/salmonella.htm.

Callaway, T.R.; Elder, R.O.; Keen, J.E.; Anderson, R.C. and Nisbet, D.J. (2003): Forage feeding to reduce preharvest Escherichia coli populations in cattle, a review. J. Dairy Sci. 86: 852-860. http://dx.doi.org/10.3168/jds. S0022-0302 (03)73668-6.
Collins, C.H. and Lyne, P.M. (1984): Microbiological methods $5^{\text {th }}$ microbiology laboratory manual, British Liberary, Butter Wort Inc., London, UK.

Cruickshank, R.; Duguid, J.; Marmion, B. and Swain, R.H. (1975): Medical Microbiology. $12^{\text {th }}$ Ed., Edinburg, London and New York.

De Felip, G. and Toti, L. (1984): Food poisoning caused by gram-negative bacteria in milk products. Microbiological Alimentation Nutrition 2, 251-256.

E.O.S.Q.C. (2005): Egyptian Organization for Standardization and Quality Control. Egyptian Standards (E.S.): "mozzarella cheese 1008-5.

El-Gazzar, F.E. and Marth, E.H. (1992): Salmonellae, salmonellosis, and dairy foods: A review. J. Dairy Sci. 75: 2327-2343.

FAO "Food and Agriculture Organization" (1992): Manual of Food Quality Control. 4. Rev. 1. Microbiological analysis. Food and Agriculture Organization of the United Nations, Rome, Italy.

FDA (US Food and Drug Administration). (2011): CFR - Code of Federal Regulations Title 21. Accessed June 21, 2012. http:// www.accessdata. fda.gov/scripts/cdrh/cfdocs/ cfcfr/CFRSearch. cfm?CFRPart=133 and showFR=1.

Fawaz, S.; Hussein, E.I.; El Zubeir, M. and Abdelaziz, A.F. (2011): Quality Evaluation of Imported and Locally Produced Processed Cheese in Sudan. Jordan Journal of Biological Sciences.

Fox, P.F.; Guinee, T.P.; Cogan, T.M. and McSweeney, P.L. (2000): Fundamentals of cheese Science. Aspen Publishers, Inc., Gaithersburg, MD.

Francesca, L.; Alyexandra, A.; Giorgia, B.; Francesca, R.P.; Alberto, M. and Giovanni, A. (2014): Microbiological safety and quality of Mozzarella cheese assessed by the microbiological survey method. J. Dairy Sci. 97: 46-55.

Frank, J.F. (2001): Milk and dairy products. In Doyle, M.P., Beuchat, L.R., and Montville, T.J. (Eds.), Food microbiology: fundamentals and frontiers (2nd ed., pp. 111-126). Washington, DC: Am. Soc. Microbiol.

Harrigan, W.F. and MeCance, M.E. (1976): Laboratory Methods in Food: Dairy Microbiology. Academic Press London, New York, San Francisco.

Hocking, S.L. and Faedo, M. (1992): Fungi causing thread mould spoilage of vacuum packaged Cheddar cheese during maturation. International Journal of Food Microbiology. 16, 123-130.

Honish, L.; Predy, G.; Hislop, N.; Chui, L.; Kowalewska- Grochowska, K.; Trottier, L.; Kreplin, C. and Zazulak, I. (2005): An 
outbreak of E. coli O157:H7 hemorrhagic colitis associated with unpasteurized Gouda cheese. Can. J. Public Health 96: 182-184.

Huis in't Veld, J.H. (1998): Microbial and biochemical spoilage of foods: An overview. Int. J. Food Microbiol. 33: 1-18.

IDF "International Dairy Federation" (1984): Interim cheese market report. Bulletin Document. No.175:10,17,22,23. http://library. wur.nl/WebQuary/clc/218046.

Jakeen, K.E.; Noha, E.A.; Alaa, G.; Mahmoud, D.; Hussein, M.G.; Sherif, A.O. and Ahmed, S. (2013): Emerging of coagulase negative staphylococci as a cause of mastitis in dairy animals: An environmental hazard I. International Journal of Veterinary Science and Medicine (1) 74-78.

Jana, A.H. and Mandal, P.K.V. (2011): Manufacturing and quality of mozzarella cheese. A review. International Journal of dairy science 6 (4): 199-226.

Jay, J.M. (2000): Staphylococcal gastroenteritis. In Modern Food Microbiology 6th edn, ed. Heldman, D.R. pp. 441-455. Gaithersburg, Maryland: Aspen publishers Inc.

Kauffman, G. (1974): Kauffmann white scheme. J. Acta. Path. Microbiol. Sci., 61: 385.

Kikuchi, M.; Matsumoto, Y.; Xue Mei, S. and Takao, $S$. (1996): Incidence and significance of thermoduric bacteria in farm milk supplies and commercial pasteurized milk. Anim. Sci. Technol. 67: 265-272.

Kok, T.; Worswich, D. and Gowans, E. (1996): Some serological techniques for microbial and viral infections. In Practical Medical Microbiology (Collee, J.; Fraser, A.; Marmion, B. and Simmons, A., eds.), $14^{\text {th }}$ ed., Edinburgh, Churchill Livingstone, UK.

Lachia, R.; Genigeogis, C. and Hoeprich, P. (1971): Meta chromatie agar- diffusion methods for detecting Staphylococcal nuclease activity. Appl. Microbiol. 21: 585:587.

Loralyn, H.L. and Robert, T.M. (2009): Microbiological Spoilage of Dairy Products. Compendium of the Microbiological Spoilage 41 of Foods and Beverages, Food Microbiology and Food Safety, DOI 10.1007/978-1-4419-0826-1.

MacFaddin, J.F. (1976): Biochemical tests for identification medical bacteria. Warery Press Inc, Baltimore, Md. 21202 USA.

Marth, H.E. and Steele, L.J. (2001): Cheese. Applied Dairy Microbiology. 2nd edition. Marcel Dekker, Inc., New York, pp. 354-358.

Nanu, E.; Latha, C.; Sunil, B.; Prejit, B.; Thomas, M. and Vrinda Menon, K. (2007): Quality assurance and public health safety of raw milk at the production point. Am. J. Food Technol. 2: 145-152. http:// dx.doi.org/10.3923/ajar. 2011.176.185.
Raimundo, D.C.; Travaglini, R.G.; Souza, G.O.; Starikoff, K.R.; Sanches, S.A.; Souza, O.B.; Balian, S.C. and Telles, E.O. (2013): Methods for thermal inactivation of pathogens in mozzarella: a comparison between stretching and pasteurization Arq. Bras. Med. Vet. Zootec., v.65, n.2, p.582-588.

Rasooly, R. and Do, P.M. (2010): Shiga toxin Stx2 is heat-stable and not inactivated by pasteurization. Int. J. Food Microbiol. 136: 290-294.

Rasooly, R.; Do, P.M.; Griffey, S.M.; Vilches-Moure, J.G. and Friedman, M. (2010): Ingested shiga toxin 2 (Stx2) causes histopathological changes in kidney, spleen, and thymus tissues and mortality in mice. J. Agric. Food Chem. 58: 9281-9286.

Ruegg, P.L. (2003): Practical food safety interventions for dairy production. J. Dairy Sci. 86 (E. Suppl.): E1-E9. http://dx.doi. org/10.3168/jds.S0022-0302(03)74034-X.

Schlesser, J.E.; Gerdes, R.; Ravishankar, S.; Madsen, K.; Mowbray, J. and Teo, A.Y. (2006): Survival of a five-strain cocktail of Escherichia coli O157:H7 during the 60-day aging period of Cheddar cheese made from unpasteurized milk. J. Food Prot. 69: 990-998.

Sherfi, S.A.; Aradaib, I.E. and Dirar, H.A. (2006): Evaluation of polymerase chain reaction for rapid detection of $E$. coli strains: A preliminary study. Asian J. Cell Biol. 1:9-13. http://dx.doi. org/10.3923/ajcb.2006.9.13.

Strachan, N.J.C.; Doyle, M.P.; Kasuga, F.; Rotariu, $O$. and Ogden, I.D. (2005): Dose response modeling of Escherichia coli $\mathrm{O} 157$ incorporating data from foodborne and environmental outbreaks. Int. J. Food Microbiol. 103: 35-47.

Tanweer, A.G. (2011): Effect of MAP on microbiological quality of Mozzarella cheese stored in different packages at $7 \pm 1{ }^{\circ} \mathrm{C}$.J Food Sci Technol. 48(1): 120-123.

Varga, L. (2007): Microbiological quality of commercial dairy products. Pages $487-494$ in Communicating Current Research and Educational Topics and Trends in Applied Microbiology. Formatex Microbiology Series (1). A. Mendez-Vilas, ed. Formatex, Badajoz, Spain.

WHO "World Health Organization" (2002): First pan- European conference on food quality and safety: Foodborne diseases are on the rises in Europe - FAO - WHO call for better consumer protection.

Wallace, H.; Andrews; Andrew Jacobson and Thomas Hammack (2009): Bacteriological Analytical Manual. Salmonella. Ch. 5 November 2011 Version.

Wells, J.G.; Shipman, L.D.; Greene, K.D.; Sowers, E.G.; Green, J.H.; Cameron, D.N.; Downes, 
F.P.; Martin, M.L.; Griffin, S.; Ostroff, M.; Potter, M.E.; Tauxe, R.V. and Wachsmuth, I.K. (1991): Isolation of Escherichia coli serotype O157:H7 and other Shiga-like toxinproducing E. coli from dairy cattle. J. Clin. Microbiol. 29: 985-989.
Zansky, S.; Wallace.; Schoon maker - Bopp, D.; Smith, P.; Ramsey, F.; Painter, J.; Gupta, A.; Kalluri, P. and Noviello, S. (2002): From the Centers for Disease Control and Prevention. Outbreak of multidrug resistant Salmonlla newport. USA: JAMA 288: 951-953.

\section{التقييم الميكروبيولوجى لجبن الموتزاريلا \\ دينا نور (للين على ، ولاء محمود على الثريف}

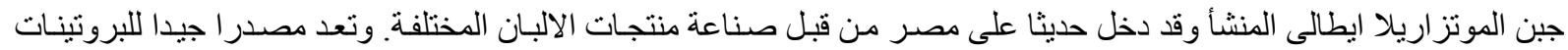

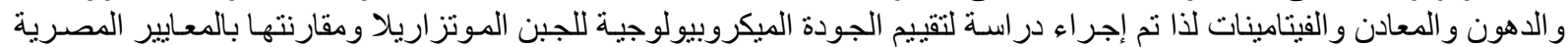

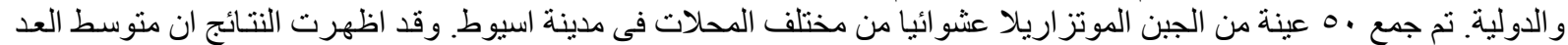

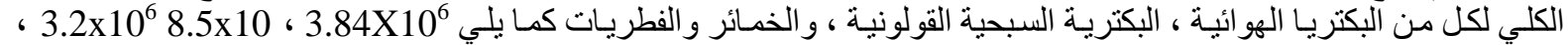

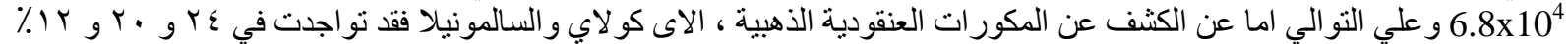

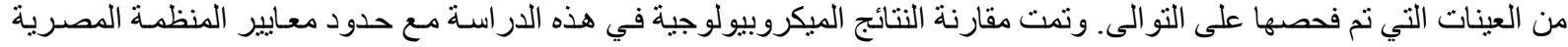
و المعايير الدولية. 